\title{
The Peripheral Arterial disease study (PERART/ ARTPER): prevalence and risk factors in the general population
}

\author{
María Teresa Alzamora ${ }^{1,2,3^{*}}$, Rosa Forés ${ }^{1,3}$, José Miguel Baena-Díez ${ }^{4}$, Guillem Pera ${ }^{3}$, Pere Toran $^{3}$, Marta Sorribes ${ }^{5}$, \\ Marisa Vicheto ${ }^{1}$, María Dolores Reina ${ }^{6}$, Amparo Sancho $^{7}$, Carlos Albaladejo ${ }^{8}$, Judith Llussà ${ }^{9}$, \\ the PERART/ARTPER study group
}

\begin{abstract}
Background: The early diagnosis of atherosclerotic disease is essential for developing preventive strategies in populations at high risk and acting when the disease is still asymptomatic. A low ankle-arm index is a good marker of vascular events and may be diminished without presenting symptomatology (silent peripheral arterial disease). The aim of the study is to know the prevalence and associated risk factors of peripheral arterial disease in the general population.

Methods: We performed a cross-sectional, multicentre, population-based study in 3786 individuals $>49$ years, randomly selected in 28 primary care centres in Barcelona (Spain). Peripheral arterial disease was evaluated using the ankle-arm index. Values $<0.9$ were considered as peripheral arterial disease.

Results: The prevalence (95\% confidence interval) of peripheral arterial disease was $7.6 \%$ (6.7-8.4), (males 10.2\% (9.2-11.2), females 5.3\% (4.6-6.0); $p<0.001)$.

Multivariate analysis showed the following risk factors: male sex [odds ratio (OR) 1.62; 95\% confidence interval 1.012.59]; age OR 2.00 per 10 years (1.64-2.44); inability to perform physical activity [OR 1.77 (1.17-2.68) for mild limitation to OR 7.08 (2.61-19.16) for breathless performing any activity]; smoking [OR 2.19 (1.34-3.58) for former smokers and OR 3.83 (2.23-6.58) for current smokers]; hypertension OR 1.85 (1.29-2.65); diabetes OR 2.01 (1.42-2.83); previous cardiovascular disease OR 2.19 (1.52-3.15); hypercholesterolemia OR 1.55 (1.11-2.18); hypertriglyceridemia OR 1.55 (1.10-2.19). Body mass index $\geq 25 \mathrm{Kg} / \mathrm{m}^{2}$ OR 0.57 (0.38-0.87) and walking $>7$ hours/week OR 0.67 (0.49-0.94) were found as protector factors.

Conclusions: The prevalence of peripheral arterial disease is low, higher in males and increases with age in both sexes. In addition to previously described risk factors we found a protector effect in physical exercise and overweight.
\end{abstract}

\section{Background}

The prevention and early diagnosis of atherosclerotic disease is one of the essential objectives in the field of cardiovascular disease since it is the main cause of mortality in developed countries. In the European Union these diseases represent approximately $40 \%$ of the deaths in both men and women [1]. Atherosclerosis is currently considered a chronic, progressive systemic

\footnotetext{
* Correspondence: maiteal2007@gmail.com
${ }^{1}$ Primary Healthcare Centre Riu Nord-Riu Sud, Institut Català de la Salut,

* Correspondence: maiteal2007@gmail.com Santa Coloma de Gramenet, Spain
}

disease of multifactorial aetiology [2] including arterial hypertension, hypercholesterolemia, diabetes mellitus and smoking as modifiable risk factors and age and sex as non modifiable factors [3]. These factors have been integrated in prediction tables based on regression models with the aim of detecting the population with a high risk of cardiovascular events [4]. However, the sensitivity and positive predictive value of these tables is low, and thus, most cardiovascular disease are produced in subjects without a high risk [4]. It is therefore important to develop markers of silent atherosclerotic disease which 
will help to better identify subjects at high risk of developing peripheral arterial disease in order to implement preventive measures. In addition, atherosclerotic disease remains clinically silent during most of the evolutionary process until phenomena of complications of atheroma plaques suddenly appear and lead to ischaemic vascular events. Therefore, from a primary prevention point of view, it is very important to develop strategies which allow identification of patients with atherosclerosis in subclinical stages, with primary care being the optimum setting for accessibility.

Peripheral arterial disease is a common manifestation of atherosclerosis and is characterized by increasing incidence of morbi-mortality [5]. Peripheral arterial disease is a powerful predictor of cardio and cerebrovascular events and is associated with an increase in mortality of up to $30 \%$ at 5 years and $50 \%$ at 10 years [5-7] thereby making early detection of this disease fundamental.

The prevalence of peripheral arterial disease varies greatly depending on the population studied, on the definition of peripheral arterial disease used (symptomatic or not), the diagnostic method, age, sex and the presence of other risk factors. Most studies have been carried out in populations at high risk, with few having been performed in countries of low risk [8-16]. The prevalence of peripheral arterial disease in countries with low cardiovascular risk is uncertain.

Underdiagnosis of peripheral arterial disease is very high since a very large proportion of these patients is asymptomatic [17]. The ankle-arm index is the most effective tool used to screen for peripheral arterial disease $[18,19]$. Compared with angiography, an ankle arm index $<0.9$ presents a sensitivity of $95 \%$ and a specificity of $99 \%$ for the detection of stenosis $\geq 50 \%$ [20], with the reliability of this test being good when performed by trained personnel [18-21].

The wide range of prevalence reported in the literature and the low number of studies in countries of low risk such as Spain led to the design of this study, the aim of which was to know the prevalence of peripheral arterial disease using the calculation of the ankle arm index in a general population over the age of 49 years and to determine the risk factors associated with a pathologic ankle arm index.

\section{Methods}

A detailed description of the methodology of the study has been published elsewhere [22].

Briefly, this was a cross-sectional, multicentre, descriptive, population-based study aim at determining the prevalence of symptomatic and asymptomatic peripheral arterial disease and related factors in a general population ascribed in primary care. Individuals were randomly selected (simple random sampling) from a database, which is more exhaustive and updated than the census, containing the population ascribed in the centers participating in the study. The randomly selected individuals were invited to participate in the study by phone. If the individuals were not found, up to 5 calls were made at different hours and days of the week to contact them. After agreement to participate subjects were given an appointment to perform an interview, blood sample extraction and anthropometric measurements, including ankle-arm index.

A total of 28 primary healthcare centers within the metropolitan area of the city of Barcelona and the county of Barcelonès Nord-Maresme, including urban and semi-rural centers, participated in the study. Finally, from September 2006 to June 2008, a total of 3786 patients over the age of 49 years were included in the study.

\section{Data collection}

The ankle arm index examination of the subjects was carried out in the participating centres by two healthcare professionals trained in the technique, under standardized conditions. A standardized Doppler Ultrasonic device was used (Mini-Dopplex D 900-P, Huntleigh Healthcare, $8 \mathrm{MHz}$ ). Ankle-arm index was performed in the two paramaleolar arteries of both lower extremities. For each leg the ankle-arm index was the ratio of the higher of the two systolic pressures (tibial posterior and anterior artery) and arm systolic pressure using the systolic pressure of the highest arm. If the ankle-arm index was $<0.9$ the technique was performed by the other professional. In cases in which the second professional found an ankle arm index $\geq 0.9$ the first repeated the test and the latter value was considered as the final result.

The following variables were collected: demographic and lifestyle, including smoking and physical activity with a validated questionnaire, self-reported and clinical history of previous cardiovascular disease (acute myocardial infarction, angina, stroke and transient ischaemic attack), intermittent claudication, hypercholesterolemia, diabetes mellitus, arterial hypertension; anthropometric variables (height, weight, and waist circumference), blood analysis (total cholesterol, HDL-cholesterol, triglycerides, and glycaemia); cardiovascular risk using the Framingham-Wilson equations, Framingham calibrated by the REGICOR and SCORE groups; metabolic syndrome (NCEP criteria) [23]; and the Edinburgh vascular questionnaire $[8,15]$.

\section{Statistical analysis}

The prevalence of peripheral arterial disease was computed in the whole sample. However, patients with 
Mönckeberg sclerosis, indicated as an ankle arm index $>1.4$ (arterial calcification) were excluded from further analyses involving potential associated risk factors with peripheral arterial disease. Comparison of categorical variables was performed using chi squared tests and for continuous variables the t-test was used. In addition, non parametric tests were used when distribution requirements of the variables analyzed were not fulfilled. Logistic regression models (LRM) were adjusted using peripheral arterial disease as the dependent variable. The individual effect, measured with the odds ratios [OR, (95\% confidence interval)] of the potential risk factors, was studied in age- and sex-adjusted LRM. Multivariate LRM were thereafter constructed to assess the independent effects of each variable adjusted for the other in the model. Best models were selected taking into account the correlation between variables and the Akaike Information Criteria (AIC) [24]. Only variables with $\mathrm{p}<0.05$ remained in the model. Significance was defined with a $\mathrm{p}$ value less than 0.05 . All tests were bilateral. Analysis was performed using Stata version 10 (StataCorp, College Station, TX, USA, 2007).

\section{Ethics}

This study was approved by the local Ethics Committee (IDIAP Jordi Gol Foundation of Investigation in Primary Care and Instituto de Salud Carlos III). Informed written consent was obtained from all the participants. Likewise, the recommendations of the World Medical Association Declaration of Helsinki were follow.

\section{Ethical considerations}

The authors of this manuscript have certified that they comply with the Principles of Ethical Publishing in BMC Public Health.

\section{Results}

The percentage of participation in the study was of $63 \%$, with 3786 participants $>49$ years $[1746$ men $(46.1 \%)$ and 2040 women $(53.9 \%)]$ with a mean age of 64.9 years \pm 8.9 being included. Of these, 286 patients had an anklearm index $<0.9$. The prevalence of peripheral arterial disease in the total population was $7.6 \%$ (95\% confidence interval 6.7-8.4) (men 10.2\% (9.2-11.2), women 5.3\% (4.6-6.0); $\mathrm{p}<0.001)$. For each 10 years of increased age, the prevalence of peripheral arterial disease doubled. Figure 1. Arterial calcification was diagnosed in 235 patients, representing $6.2 \%(5.5-7.0)$ of the patients (men: $8.5 \%$ (7.6-9.4), women: $4.2 \%(3.6-4.8)$; $\mathrm{p}<0.001$ ) who were excluded from the analysis of the factors associated with peripheral arterial disease.

Table 1 describes the sample, excluding the patients with arterial calcification according to whether peripheral arterial disease was present or not. Intermittent claudication was present in $10.0 \%$ of the subjects. Only $19.0 \%$ of the patients with peripheral arterial disease had been previously diagnosed. Of those who had not been previously diagnosed $29.3 \%$ presented symptoms of IC. More than $36.8 \%$ of the subjects presented obesity. Most of the patients were classified as having low or intermediate cardiovascular risk according to the tables, while $10.8 \%$ had already presented cardiovascular disease.

\section{Risk factors for the presence of peripheral arterial disease according to logistic regression analysis}

Table 2 shows the results of the individual analysis of the risk factors associated with the presence of peripheral arterial disease according to the LRM adjusted for age, sex and centre and table 3 describes the results of the multivariate analysis according to gender. Walking more than 7 hours weekly (OR 0.67) and overweight/ obesity (OR 0.57 ) were protector factors on multivariate analysis, although on stratification by sex, they were only statistically significant in women. Male gender (OR 1.62), age (OR 2.00 per 10 years), difficulty in performing physical exercise (OR 7.08 breathlessness performing any activity) and smoking (OR 3.83 for current smokers) were positively associated with peripheral arterial disease in both sexes. Hypertension (OR 1.85), diabetes (OR 2.01) and previous CDV (OR 2.19) were associated with peripheral arterial disease overall and among men, and hypercholesterolemia (OR 1.55) and high triglycerides (OR 1.55) were associated with peripheral arterial disease overall and among women only. Variables only significant for one gender in the multivariate analysis showed a similar trend in both sexes. Although education, occupation and IC were associated with peripheral arterial disease in the age- and sex-adjusted models, these factors had no significant effect in the multivariate models. Stroke, transient ischaemic attack, angina or and myocardial infarction were related to peripheral arterial disease in the age- and sex-adjusted model but were collapsed into a single cardiovascular disease variable in the multivariate model providing better AIC indexes. Information regarding cardiovascular disease risk tables or metabolic syndrome was not included in the multivariate model since most of their components were already included. Nevertheless, a significant association (table 2) was observed between the metabolic syndrome and peripheral arterial disease [OR 1.79 CI 95\% (1.36-2.36)] and these variables showed a positive and significant association with peripheral arterial disease in the age and sex adjusted models.

\section{Discussion}

The results of the present study indicate that the prevalence of peripheral arterial disease using the ankle-arm 


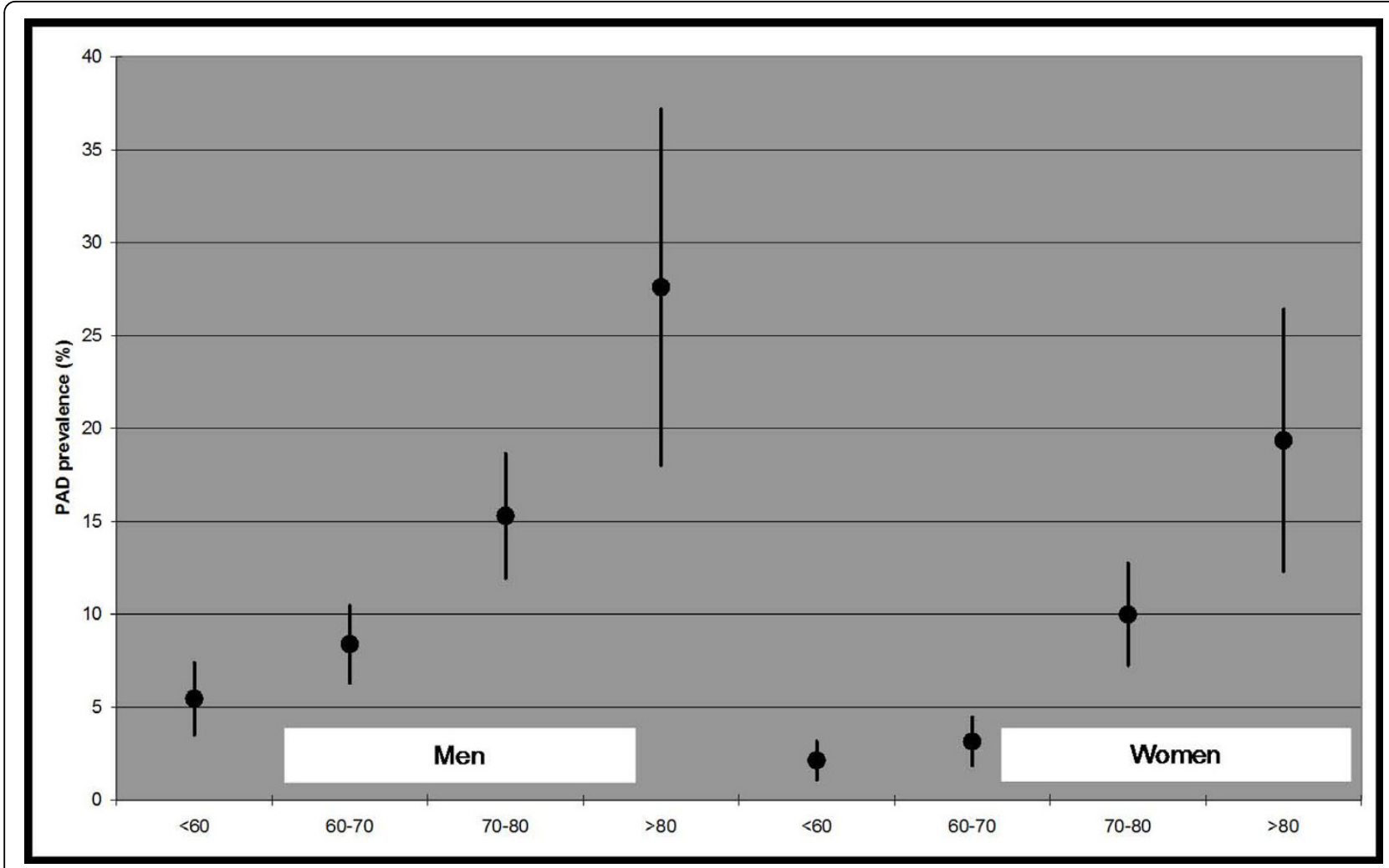

Figure 1 Prevalence of peripheral arterial disease and $95 \%$ confidence interval by age and sex.

index (7.6\%) is lower in a country of low cardiovascular risk such as Spain in relation to other countries with a higher risk [8-13]. Thus, our results coincide with studies which have reported lower values of cardiovascular disease such as ischaemic heart disease [25]. In another Spanish study [15], the prevalence of peripheral arterial disease was lower (4.5\%). Nonetheless, the age of the subjects studied was from 35 to 79 years which could explain the difference with our results considering that it is well known that the prevalence of cardiovascular disease increases with age [7].

The prevalence of peripheral arterial disease in the general population is not well known in countries of low risk. In Spain, all the previous studies have been undertaken in populations at high risk or well selected for different factors: male sex, smokers, diabetics, metabolic syndrome or previous cardiovascular disease. In these studies the prevalence ranged from $3.9 \%$ to $26.2 \%$ according to the population studied [25-30], with the high prevalence among hospitalized (26.2\%) [27] and diabetic patients (21.4\%) [30] being of note. The low prevalence of peripheral arterial disease in countries with low cardiovascular risk [25] but a high prevalence of cardiovascular risk factors (French paradox) could be explained by protective factors in Mediterranean countries, such as dietetic factors. Studies in Spain have confirmed this low prevalence of peripheral arterial disease $[15,16]$, coronary heart disease $[31,32]$ and stroke $[33,34]$ compared with studies conducted in Northern Europe.

One alarming data of our study was the under diagnosis of peripheral arterial disease of $81.0 \%$ which, according to some authors, may be attributed to the large number of patients $(80-90 \%)$ who remain asymptomatic and that the ankle arm index is not routinely evaluated in primary care offices. It is important to note that in the present study $33.8 \%$ of the patients with a pathologic ankle arm index presented clinical manifestations of IC, as defined by the Edinburgh questionnaire $[8,35,36]$. The patients may attribute this symptomatology to other diseases or pathological processes. In most of the studies published, the IC values among patients with peripheral arterial disease were between 5\% and 29.6\% $[10,12]$, with the exception of the study by Coni et al. [37] in which the prevalence of IC was very high $(37.5 \%)$ and similar to that of our study, although, in contrast with the previous study, we used the Edinburgh questionnaire.

The proportion of patients with arterial calcification was of note $(6.2 \%)$. Its clinical significance has been 
Table 1 Sample characteristics by peripheral arterial disease

\begin{tabular}{|c|c|c|c|}
\hline & $\begin{array}{l}\text { PAD } \\
n=286\end{array}$ & $\begin{array}{l}\text { Control }^{\mathrm{a}} \\
\mathrm{n}=3265\end{array}$ & $p$-value ${ }^{\mathrm{b}}$ \\
\hline Gender & & & $<0.001$ \\
\hline Men & $11.1(178)$ & $88.9(1419)$ & \\
\hline Women & $5.5(108)$ & $94.5(1846)$ & \\
\hline Age (years) (mean $\pm S D$ ) & $70.70 \pm 9.26$ & $64.22 \pm 8.60$ & $<0.001$ \\
\hline Education & & & $<0.001$ \\
\hline Illiterate & $14.2(30)$ & $85.8(182)$ & \\
\hline Primary school & $8.1(196)$ & $91.9(2229)$ & \\
\hline Secondary school & $5.4(27)$ & $94.6(477)$ & \\
\hline High school & $5.7(7)$ & $94.3(116)$ & \\
\hline University & $3.4(4)$ & $96.6(112)$ & \\
\hline Occupation status & & & $<0.001$ \\
\hline Currently working & $3.6(30)$ & 96.4 (813) & \\
\hline Housewife & $4.7(34)$ & $95.3(689)$ & \\
\hline Retired & $12.2(192)$ & $87.8(1380)$ & \\
\hline Unemployed & $3.9(6)$ & $96.1(148)$ & \\
\hline Disabled & $11.1(15)$ & $88.9(120)$ & \\
\hline Other & $6.3(3)$ & $93.8(45)$ & \\
\hline Ability to perform physical activity & & & $<0.001$ \\
\hline No limitation & $3.8(51)$ & $96.2(1291)$ & \\
\hline Mild limitation & $8.5(150)$ & $91.5(1618)$ & \\
\hline Only able to do light activity & $19.9(72)$ & $80.1(289)$ & \\
\hline Breathless with any activity & $29.3(12)$ & $70.7(29)$ & \\
\hline Walking (hours/week) & & & 0.376 \\
\hline $0-3$ & $7.2(65)$ & $92.8(844)$ & \\
\hline$>3-7$ & $8.0(61)$ & $92.0(697)$ & \\
\hline$>7$ & $6.4(86)$ & $93.6(1252)$ & \\
\hline Tobacco smoking & & & $<0.001$ \\
\hline Never smoker & $5.3(104)$ & $94.7(1871)$ & \\
\hline Former smoker & $11.3(108)$ & $88.7(844)$ & \\
\hline Current smoker & $11.9(74)$ & $88.1(550)$ & \\
\hline Claudication (people with leg pain when walking and no pain when stop) & & & $<0.001$ \\
\hline No & $5.9(184)$ & $94.1(2952)$ & \\
\hline Yes & $26.9(94)$ & $73.1(255)$ & \\
\hline Obesity & & & 0.164 \\
\hline Underweight/Average (BMI<25) & $9.7(61)$ & $90.3(566)$ & \\
\hline Overweight $(25 \leq \mathrm{BMI}<30)$ & $7.3(118)$ & $92.7(1496)$ & \\
\hline Obese $(\mathrm{BMI} \geq 30)$ & $8.2(107)$ & $91.8(1198)$ & \\
\hline Waist circumference & & & 0.035 \\
\hline 1st tertile ${ }^{c}$ & $6.9(78)$ & $93.1(1060)$ & \\
\hline 2nd tertile & $7.6(89)$ & $92.4(1076)$ & \\
\hline 3rd tertile & $9.7(118)$ & $90.3(1104)$ & \\
\hline Hypertension (medical record) & & & $<0.001$ \\
\hline No & $4.7(88)$ & $95.3(1791)$ & \\
\hline Yes & $11.9(193)$ & $88.1(1431)$ & \\
\hline Hypercholesterolemia (medical record) & & & $<0.001$ \\
\hline No & $6.0(108)$ & $94.0(1691)$ & \\
\hline Yes & $10.2(170)$ & $89.8(1501)$ & \\
\hline
\end{tabular}


Table 1: Sample characteristics by peripheral arterial disease (Continued)

\begin{tabular}{|c|c|c|c|}
\hline \multicolumn{4}{|l|}{ Blood analysis (mean \pm SD) } \\
\hline Total cholesterol (mg/dL) & $210.03 \pm 42.10$ & $216.53 \pm 38.48$ & 0.007 \\
\hline $\mathrm{HDL}(\mathrm{mg} / \mathrm{dL})$ & $52.30 \pm 14.09$ & $56.03 \pm 14.48$ & $<0.001$ \\
\hline Triglycerides (blood analysis) & & & $<0.001$ \\
\hline Normal & $6.9(181)$ & $93.1(2447)$ & \\
\hline High ( $\geq 150$ mg/dL) & $11.8(105)$ & $88.2(786)$ & \\
\hline Diabetes (medical record) & & & $<0.001$ \\
\hline No & $6.4(191)$ & $93.6(2802)$ & \\
\hline Yes & $17.0(95)$ & $83.0(463)$ & \\
\hline Stroke (medical record) & & & $<0.001$ \\
\hline No & & $7.6(260) 92.4(3176)$ & \\
\hline Yes & & $24.4(22) 75.6(68)$ & \\
\hline Transient ischaemic attack (medical record) & & & 0.001 \\
\hline No & $7.7(266)$ & $92.3(3167)$ & \\
\hline Yes & $17.5(14)$ & $82.5(66)$ & \\
\hline Angor (medical record) & & & $<0.001$ \\
\hline No & $7.5(253)$ & $92.5(3105)$ & \\
\hline Yes & $19.0(31)$ & $81.0(132)$ & \\
\hline Myocardial infarction (medical record) & & & $<0.001$ \\
\hline No & $7.2(245)$ & $92.8(3148)$ & \\
\hline Yes & $29.0(38)$ & $71.0(93)$ & \\
\hline Framingham index (aged $\leq 74$ ) & & & $<0.001$ \\
\hline$<10$ & $2.9(32)$ & $97.1(1081)$ & \\
\hline $10-20$ & $5.5(65)$ & $94.5(1120)$ & \\
\hline$>20$ & $13.0(81)$ & $87.0(542)$ & \\
\hline REGICOR index (aged $\leq 74))$ & & & $<0.001$ \\
\hline$<5$ & $3.1(41)$ & $96.9(1295)$ & \\
\hline $5-10$ & $7.0(89)$ & $93.0(1177)$ & \\
\hline$>10$ & $15.0(48)$ & $85.0(271)$ & \\
\hline SCORE index (aged<65) & & & $<0.001$ \\
\hline$<2.5$ & $2.4(27)$ & $97.6(1105)$ & \\
\hline $2.5-5$ & $4.0(18)$ & $96.0(427)$ & \\
\hline$>5$ & $10.9(37)$ & $89.1(302)$ & \\
\hline Metabolic syndrome (NCEP) & & & $<0.001$ \\
\hline No & $7.2(198)$ & $92.8(2559)$ & \\
\hline Yes & $11.4(88)$ & $88.6(685)$ & \\
\hline
\end{tabular}

All values are presented as prevalence of healthy and peripheral arterial disease as percent $(\mathrm{n})$ unless otherwise specified. SD: standard deviation. BMI: Body mass index expressed in $\mathrm{Kg} / \mathrm{m}^{2}$.

a Patients with calcification excluded.

${ }^{b} \mathrm{p}$ value for a chi-squared test (categorical variable) and t-test (continuous variable). Fisher exact test and rank sum tests have also been performed for categorical and continuous variables respectively leading to similar $\mathrm{p}$ values.

c Sex-specific tertiles. Cut points are $97 \mathrm{~cm}$ and $105 \mathrm{~cm}$ for men and $90 \mathrm{~cm}$ and $101 \mathrm{~cm}$ for women.

little studied. Nonetheless, it has recently been shown to be associated with a greater risk of morbi-mortality [38] although not as important as an ankle arm index $<0.9$. These patients were excluded from the analysis of the associated factors to allow better comparability among healthy patients and those with peripheral arterial disease. This will be studied in the future.

Similar to other studies, the present series found a higher prevalence of peripheral arterial disease in men which progressively rose with age in both sexes. In women, a protector effect was found with physical exercise (walking $>7$ hours per week) and overweight, although this was not statistically significant in men. This protector effect of physical exercise may be justified by a greater development of collateral circulation, which is currently one of the therapeutic recommendations in these patients. The protector effect of obesity and overweight independent of physical exercise and other risk factors may be surprising, but a better prognosis has also been described in patients with obesity in 
Table 2 Association between peripheral arterial disease and potential risk factors. Logistic regression models adjusted by age and sex

\begin{tabular}{|c|c|c|}
\hline & OR $(95 \% \mathrm{Cl})$ & $p$-value for trend \\
\hline Men & $2.13(1.65-2.75)$ & \\
\hline Age (per 10 years) & $2.25(1.96-2.60)$ & \\
\hline Education (reference $=$ Illiterate) & & 0.011 \\
\hline Primary school & $0.65(0.42-1.00)$ & \\
\hline Secondary school & $0.55(0.31-0.99)$ & \\
\hline High school & $0.48(0.20-1.16)$ & \\
\hline University & $0.29(0.10-0.87)$ & \\
\hline \multicolumn{3}{|l|}{ Occupation status (reference $=$ Currently working) } \\
\hline Housewife & $1.02(0.57-1.83)$ & \\
\hline Retired & $1.14(0.70-1.86)$ & \\
\hline Unemployed & $1.10(0.45-2.71)$ & \\
\hline Disabled & $2.50(1.29-4.88)$ & \\
\hline Other & $1.76(0.51-6.05)$ & \\
\hline Ability to perform physical activity (reference $=$ No limitation) & & $<0.001$ \\
\hline Mild limitation & $2.07(1.47-2.92)$ & \\
\hline Only able to do light activity & $4.84(3.19-7.36)$ & \\
\hline Breathless with any activity & $6.70(3.10-14.45)$ & \\
\hline Walking (hours/week) (reference $=0-3$ ) & & 0.002 \\
\hline$>3-7$ & $0.88(0.60-1.29)$ & \\
\hline$>7$ & $0.58(0.40-0.82)$ & \\
\hline Tobacco smoking (reference $=$ Never smoker) & & $<0.001$ \\
\hline Former smoker & $2.14(1.45-3.17)$ & \\
\hline Current smoker & $3.91(2.58-5.93)$ & \\
\hline Claudication & $5.00(3.73-6.71)$ & \\
\hline Obesity (reference $=$ BMl<25) & & 0.685 \\
\hline Overweight $(25 \leq \mathrm{BMI}<30)$ & $0.67(0.48-0.94)$ & \\
\hline Obese $(\mathrm{BMI} \geq 30)$ & $0.85(0.60-1.20)$ & \\
\hline Waist circumference & & 0.174 \\
\hline 2nd tertile $e^{a}$ & $1.02(0.73-1.41)$ & \\
\hline 3rd tertile & $1.23(0.90-1.67)$ & \\
\hline Hypertension & $1.99(1.51-2.62)$ & \\
\hline Hypercholesterolemia & $1.86(1.43-2.41)$ & \\
\hline Triglycerides $\geq 150 \mathrm{mg} / \mathrm{dL}$ & $2.05(1.58-2.66)$ & \\
\hline Diabetes & $2.39(1.82-3.15)$ & \\
\hline Stroke & $2.92(1.74-4.90)$ & \\
\hline Transient ischaemic attack & $1.73(0.93-3.20)$ & \\
\hline Angor & $1.90(1.23-2.93)$ & \\
\hline Myocardial infarction & $3.81(2.50-5.82)$ & \\
\hline Framingham index (aged $\leq 74$ ) & & $<0.001$ \\
\hline $10-20$ & $1.42(0.88-2.29)$ & \\
\hline$>20$ & $2.57(1.49-4.43)$ & \\
\hline REGICOR index (aged $\leq 74)$ & & $<0.001$ \\
\hline $5-10$ & $1.60(1.05-2.43)$ & \\
\hline$>10$ & $2.61(1.55-4.38)$ & \\
\hline
\end{tabular}


Table 2: Association between peripheral arterial disease and potential risk factors. Logistic regression models adjusted by age and sex (Continued)

\begin{tabular}{ll}
\hline SCORE index (aged $<65)$ & $<0.001$ \\
$2.5-5$ & $1.43(0.71-2.89)$ \\
$>5$ & $3.99(2.00-7.95)$ \\
Metabolic syndrome (NCEP) & $1.79(1.36-2.36)$ \\
\hline
\end{tabular}

Patients with calcification excluded.

All models adjusted for age, sex and centre.

BMI: Body mass index.

${ }^{\text {a }}$ Sex-specific tertiles. Cut points are $97 \mathrm{~cm}$ and $105 \mathrm{~cm}$ for men and $90 \mathrm{~cm}$ and $101 \mathrm{~cm}$ for women.

heath failure and a lower incidence of acute myocardial infarction $[39,40]$. However, we did not find any relationship with waist circumference, although on adjusting for the body mass index (BMI) we did find a relationship with the second [OR $1.25(0.87-1.81)]$ and the third tertile [OR 1.56 (1.02-2.37)] compared to the first tertile, which disappeared on adjustment for the remaining variables in the multivariate model.

With regard to studies evaluating the association with different factors, our results coincide in age [8-13], male gender [8-13], hypertension [9-11], diabetes [11,12], smoking [10-12], and history of cardiovascular disease $[9,10]$. In the present study we found an association with hypercholesterolemia and hypertriglyceridemia in women. In other studies [11,12], an association has also been reported with hypercholesterolemia, while the results related to triglycerides in the literature are contradictory [9].
With respect to limitations of the study, as usually occurs in population-based studies in Spain, women were slightly over-represented [14]. Although the data from the census were not used, in Spain the use of the population assigned to the primary care centres is preferable since it is more exhaustive and updated than that of the census [41]. On the other hand, the crosssectional design of the study did not allow determination of the causal effect of the different factors associated with peripheral arterial disease.

The technical ease of the ankle-arm index and it ready adoption in the primary care offices has replaced the use of carotid echo-Doppler for detecting patients with high cardiovascular risk. However, a large proportion of the population has an intermediate risk, thus it remains to be defined in which patients ankle arm index should be a priority. According to the present study these patients would include: males, aged over 60 years, smokers or

Table 3 Association between peripheral arterial disease and potential risk factors. Multivariate logistic regression models by sex.

\begin{tabular}{|c|c|c|c|}
\hline & Total & Men & Women \\
\hline & OR $(95 \% \mathrm{Cl})$ & OR $(95 \% \mathrm{Cl})$ & OR $(95 \% \mathrm{Cl})$ \\
\hline Men & $1.62(1.01-2.59)$ & & \\
\hline Age (×10 years) & $2.00(1.64-2.44)$ & $1.83(1.42-2.36)$ & $2.17(1.52-3.09)$ \\
\hline PA Mild limitation ${ }^{a}$ & $1.77(1.17-2.68)$ & $2.16(1.33-3.51)$ & $0.92(0.42-2.03)$ \\
\hline PA Only able light activity ${ }^{a}$ & $3.64(2.16-6.13)$ & $4.09(2.12-7.91)$ & $2.39(0.97-5.90)$ \\
\hline PA Breathless any activity ${ }^{a}$ & $7.08(2.61-19.2)$ & $7.47(1.87-29.8)$ & $5.40(1.14-25.7)$ \\
\hline$>7 \mathrm{~h} / \mathrm{w}$ walking ${ }^{\mathrm{b}}$ & $0.67(0.49-0.94)$ & $0.82(0.55-1.23)$ & $0.43(0.22-0.82)$ \\
\hline Former smoker ${ }^{c}$ & $2.19(1.34-3.58)$ & $2.48(1.26-4.90)$ & $1.47(0.52-4.11)$ \\
\hline Current smoker $^{c}$ & $3.83(2.23-6.58)$ & $4.18(2.01-8.69)$ & $4.00(1.59-10.1)$ \\
\hline $\mathrm{BMI} \geq 25 \mathrm{Kg} / \mathrm{m}^{2}$ & $0.57(0.38-0.87)$ & $0.65(0.39-1.08)$ & $0.43(0.20-0.92)$ \\
\hline Hypertension & $1.85(1.29-2.65)$ & $1.78(1.16-2.72)$ & $2.03(0.99-4.149$ \\
\hline Hypercholesterolemia & $1.55(1.11-2.18)$ & $1.36(0.90-2.07)$ & $1.87(1.03-3.40)$ \\
\hline High triglycerides & $1.55(1.10-2.19)$ & $1.27(0.82-1.98)$ & $2.29(1.29-4.05)$ \\
\hline Diabetes & $2.01(1.42-2.83)$ & $2.27(1.50-3.44)$ & $1.59(0.85-2.99)$ \\
\hline Cardiovascular disease & $2.19(1.52-3.15)$ & $2.54(1.66-3.90)$ & $1.43(0.67-3.02)$ \\
\hline
\end{tabular}

Patients with calcification excluded.

All models adjusted for the variables included in the table and centre.

PA: Physical activity (reference $=$ No limitation), BMI: Body mass index

${ }^{a} \mathrm{p}$ for trend are $<0.001$ (total and men) and 0.009 (women) for physical activity

${ }^{\mathrm{b}}$ Reference $=$ less than or equal to 7 hours walking per week

${ }^{c} \mathrm{p}$ for trend are $<0.001$ (total and men) and 0.003 (women) for smoking. 
ex-smokers, those with clinical manifestations of IC or difficulty in performing physical activity, patients with hypertension, diabetes or hypertriglyceridemia. The addition of ankle-arm index in prediction tables of cardiovascular risk can improve the sensitivity and positive predictive values, especially in patients with intermediate or low cardiovascular risk.

\section{Conclusions}

In summary, the prevalence of peripheral arterial disease in our population of low-medium risk is lower compared to studies carried out in countries of high risk. Our results coincide with most of the studies published on risk factors for peripheral arterial disease, but the protector effect of physical exercise and overweight is of note. It is necessary to determine the prognostic value of peripheral arterial disease compared to cardiovascular disease in a longitudinal study and to define the population in whom the use of the ankle arm index should be a priority to thereby correctly stratify the cardiovascular risk of our population beyond the use of the tables for risk of cardiovascular disease. Further studies are required to clarify the clinical significance and the association with cardiovascular risk of patients with arterial calcification and those in whom the ankle arm index cannot be determined.

\section{Abbreviations}

(CVD): Cardiovascular disease; (PAD): Peripheral arterial disease; (AAl): Anklearm index; (IC): Intermittent claudication; (LRM): Logistic regression models; (AIC): Akaike Information Criteria; (BMI): Body mass index.

\section{Acknowledgements}

\section{The PERART Study Group:}

SAP Santa Coloma de Gramenet: $M^{a}$ Dolores Reina, Juan Rubiés. CAP Riu Nord-Riu Sud: Carme Vela, Antonio Heras, Jordi Ingla, Judit Alegre, María Viozquez, Begoña López, Mercè Puente, Roser Orihuela, Amparo Gallart, Carme García, Isabel Denche, Eva Ramírez, Gloria Rodríguez, Mónica Fernández, Roser Garriga, Fina Ruíz. CAP Can Mariné: Montserrat Corroto, Mar Ansaldo, Teresa Morató, Edita Corral, Gemma García, Xavier Pedrós, Montse Guinart. CAP Fondo: Jordi Milozzi, María del Mar Isnard, Carmen Lisisic, Maribel Martín, Purificación Claver, Concepción Aguilera. CAP Singuerlín: Victoria Sierra, Elena Palau, Raquel Abad, José Miguel Domingo, Ana Rovira, M ${ }^{a}$ Isabel López. CAP Barri Llatí: Ginesa Acosta, Remei Moreno, Elena Fernández, Ma José de Miguel, Manuela Pozo, Ramona Villanueva. CAP Santa Rosa: Xavier González. CAP Sant Roc: Mar Domingo, Nuria Barrera,

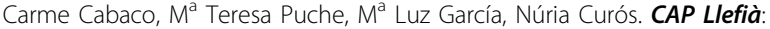
José Antonio Martín, Ferran García-Faria, Isabel López, Joaquín Fernández, Anna Rovira, Carmen Torán, María Estévez, Gemma Rico, Mª Angels Magrazo, Oriol Salvador, Sandra Moreno, Montserrat Brugada, Montserrat Boneu. CAP La Salut: Rafael Medrano, Jesús Comín, I Bagán, Jaime Teruel, María Bayés. Badalona Gestió: José Francisco Luque, J Cruz. Mataró: Magda Bundó. CAP Gatassa: German Lozano, Miren Maite Aizpura, Ma Angels Badia, Josep Sorribes, Antonio Negrete, Pilar García, Marisol Fernandez, Magalí Urrea. CAP Pineda: Mercè Pol, Antonio Gozalvez, Palmira de Paulo, Adriana Ramos, Eduardo Carrillo, Ma Carmen Barreiro, Antonio Méndez, Susana Sanz, Margarita Santaló, Mercè de Fes, Teresa Pérez, Antonio Mendez, Xavier Cantano. CAP Tordera: Nuria Albertí, Conchita García, Roser Quinta, Montserrat Maynegre, Jaume Miralbell, Meritxell Pérez, Meritxell Planas. CAP Llavaneres: $M^{a}$ José Castany, Joan Cubaró, Estíbaliz López, Albert Soria, Natalia Canovas, Manoli Marco, Nuria Forteza, $M^{a}$ José Moreno. CAP Arenys de Munt: Montserrat Tristany, Noemí Omart, Xavier Peral, Jordi Madurell. CAP
Arenys de Mar: Ricard Peiró, Sara Sancho, Martí Fradera, Teresa Llodrà, Eva Miguel, Ma José Grau, Carme Plà, Carme Fábregas, Meritxell Motosell, Esther González, Martí Sánchez, Isabel Teruella, Amalia Coll, Natalia Carrillo, Cosme Sancho. CAP Numància: Yolanda Herreros, Anna Tomás, Anna Bertolín, Nuria Fabrelles, Montserrat Porta, Marisol Moure. CAP La Marina: Josep $M^{a}$ Cots, Luís Muntanyà, Manuel García, Hector Salas, Yaina Sierra, Cristina Pozo, Consuelo Timón, Isabel Duazo, Ylenia García. CAP Sants: Teresa Bonet Salinas, Montserrat Pedra, Victoria Rubio, Jordi Altirriba, Belén Castillo. CAP Carreres Candi: Ricardo Alvarez, Rosario Silva. CAP Consell de Cent: Matilde Fuentes, Gemma Peralta, Amelia Samperio, Angela Font. CAP Magòria: Beatriz Alvarez, Eva Raido, Inés Falder, Cristina Boada, Consol Tomás. We gratefully thank Susanna Tello, Dr. Rafael Ramos and Dr. Jaume Marrugat from the Institut Municipal d'Investigació Mèdica for their collaboration in the elaboration of the questionnaire and data management; the Catalan Society of General Practitioners (CAMFIC), SAP Santa Coloma de Gramenet, SAP Barcelona Esquerra and IDIAP Jordi Gol. We also thank the Call Center of Santa Coloma de Gramenet for undertaking the telephone calls. Grant support

This work was supported by the program of Promotion in the Biomedical Investigation and Health Sciences from the Carlos III Health Institute of the Spanish Health and Consumption Ministry [PI070403].

\section{Author details}

${ }^{1}$ Primary Healthcare Centre Riu Nord-Riu Sud, Institut Català de la Salut, Santa Coloma de Gramenet, Spain. ${ }^{2}$ Department of Medicine, Universitat Autònoma de Barcelona, Barcelona Spain. ${ }^{3}$ Research Unit Metropolitana Nord, ICS-IDIAP Jordi Gol. Mataró, Spain. ${ }^{4}$ Primary Healthcare Centre La Marina, Institut Català de la Salut, Barcelona, Spain. ${ }^{5}$ Primary Healthcare Centre Numància, Institut Català de la Salut, Barcelona, Spain. ${ }^{6}$ Primary Healthcare Centre Santa Coloma de Gramenet, Institut Català de la Salut, Santa Coloma de Gramenet, Spain. ${ }^{7}$ Primary Healthcare Centre Can Mariné, Institut Català de la Salut, Santa Coloma de Gramenet, Spain. ${ }^{8}$ Primary Healthcare Centre Llefià, Institut Català de la Salut Badalona, Badalona, Spain. ${ }^{9}$ Primary Healthcare Centre Sant Roc, Institut Català de la Salut, Badalona, Spain.

\section{Authors' contributions}

MTA, JMB, MS, RF, PT, MV, MDR, JL and MB participated in the design of the study; MTA, JMB, MS, RF, PT, CA, JL and AS contributed to the coordination study; GP participated in the statistical calculations. All the authors have read and approved the final manuscript.

\section{Competing interests}

The authors declare that they have no competing interests.

Received: 13 August 2009

Accepted: 27 January 2010 Published: 27 January 2010

\section{References}

1. Eurostat, Atlas de Mortalidad: mortalidad cardiovascular. http://ec.europa. eu/health/ph_information/dissemination/diseases/cardiovascular_es.print. htm.

2. Kiechl S, Willeit J: The natural course of atherosclerosis. Part I: incidence and progression. Arterioscler Thromb Vasc Biol 1999, 19:1484-1490.

3. Grundy SM, Cleeman Jl, Daniels SR, Donato KA, Eckel RH, Franklin BA, Gordon DJ, Krauss RM, Savage PJ, Smith SC Jr, Spertus JA, Costa F. Diagnosis and management of the metabolic syndrome: an American Heart Association/National Heart, Lung, and Blood Institute Scientific Statement. Circulation 2005, 112:2735-52.

4. Grau M, Marrugat J: Risk functions and the primary prevention of cardiovascular disease. Rev Esp Cardiol 2008, 61:404-06.

5. Newman AB, Shemanski L, Manolio TA, Cushman M, Mittelmark M, Polak JF, Powe NR, Siscovick D: Ankle-arm index as a predictor of cardiovascular disease and mortality in the Cardiovascular Health Study. The Cardiovascular Health Study Group. Arterioscler Thromb Vasc Biol 1999, 19:538-45.

6. Criqui MH, Langer RD, Fronek A, Feigelson HS, Klauber MR, McCann TJ, Browner D: Mortality over a period of 10 years in patients with peripheral arterial disease. N Engl J Med 1992, 326:381-386.

7. Ankle Brachial Index Collaboration, Fowkes FG, Murray GD, Butcher I, Heald CL, Lee RJ, Chambless LE, Folsom AR, Hirsch AT, Dramaix M, 
deBacker G, Wautrecht JC, Kornitzer M, Newman AB, Cushman M, SuttonTyrrell K, Fowkes FG, Lee AJ, Price JF, d'Agostino RB, Murabito JM, Norman PE, Jamrozik K, Curb JD, Masaki KH, Rodríguez BL, Dekker JM, Bouter LM, Heine RJ, Nijpels G, Stehouwer CD, Ferrucci L, McDermott MM, Stoffers HE, Hooi JD, Knottnerus JA, Ogren M, Hedblad B, Witteman JC, Breteler MM, Hunink MG, Hofman A, Criqui MH, Langer RD, Fronek A, Hiatt WR, Hamman R, Resnick HE, Guralnik J, McDermott MM: Ankle brachial index combined with Framingham Risk Score to predict cardiovascular events and mortality: a meta-analysis. JAMA 2008, 300:197-208.

8. Fowkes FG, Housley E, Cawood EH, Macintyre CC, Ruckley CV, Prescott RJ: Edinburgh Artery Study: Prevalence of asymptomatic and symptomatic peripheral arterial disease in the general population. Int J Epidemiol 1991, 20:384-92.

9. Murabito JM, Evans JC, Nieto K, Larson MG, Levy D, Wilson PW: Prevalence and clinical correlates of peripheral arterial disease in the Framingham Offspring Study. Am Heart J 2002, 143:961-5.

10. Meijer TWouter, Hoes WArno, Rutgers Dominique, Bots LMichiel, Hofman Albert, Grobbee EDiederich: Peripheral arterial disease in the elderly: The Rotterdam study. Arterioscler Thromb Vas Biol 1998, 18:185-192.

11. Stoffers HE, Rinkens PE, Kester AD, Kaiser V, Knottnerus JA: The prevalence of asymptomatic and unrecognized peripheral arterial occlusive disease. Int J Epidemiol 1996, 25:282-90.

12. Ostchega Y, Paulose-Ram R, Dillon CF, Gu Q, Hughes JP: Prevalence of peripheral arterial disease and risk factors in persons aged 60 and older: data from the National Health and Nutrition Examination Survey 19992004. J Am Geriatr Soc 2007, 55:583-9.

13. Weatherley BD, Nelson JJ, Heiss G, Chambless LE, Sharrett AR, Nieto FJ, Folsom AR, Rosamond WD: The association of the ankle-brachial index with incident coronary heart disease: the Atherosclerosis Risk In Communities (ARIC) study, 1987-2001. BMC Cardiovasculars Disorders 2007, 7:3

14. Baena Diez JM, del Val Garcia JL, Tomas Pelegrina J, Martinez Martinez JL, Martin Penacoba R, González Tejon I: Epidemiología de las enfermedades cardiovasculares y factores de riesgo en atención primaria. Rev Esp Cardiol 2005, 58:367-73.

15. Ramos R, Quesada M, Solanas P, Subirana I, Sala J, Vila J, Masiá R, Cerezo C, Elosua $R$, Grau $M$, Cordón $F$, Juvinyà $D$, Fitó $M$, Isabel Covas $M$, Clarà $A$, Angel Muñoz M, Marrugat J, on behalf of the REGICOR Investigators: Prevalence of Symptomatic and Asymptomatic Peripheral Arterial Disease and the Value of the Ankle-brachial Index to Stratify Cardiovascular Risk. Eur J Vasc Endovasc Surg 2009, 38:305-11.

16. Blanes Jl, Cairols MA, Marrugat J: Prevalence of peripheral artery disease and its associated risk factors in Spain: The ESTIME Study. Int Angiol 2009, 28:20-5.

17. Bendermacher BL, Teijink JA, Willigendael EM, Bartelink ML, Büller HR, Peters RJ, Boiten J, Langenberg M, Prins MH: Symptomatic peripheral arterial disease: the value of a validated questionnaire and a clinical decision rule. Br J Gen Pract 2006, 56:932-7.

18. Kaiser V, Kester AD, Stoffers HE, Kitslaar PJ, Knottnerus JA: The influence of experience on the reproducibility of the ankle-brachial systolic pressure ratio in peripheral arterial occlusive disease. Eur J Vasc Endovasc Surg 1999, 18:25-29.

19. Stoffers $H E$, Kester AD, Kaiser $V$, Rinkens PE, Kitslaar PJ, Knottnerus JA: The diagnostic value of the measurement of the ankle-brachial systolic pressure index in primary health care. J Clin Epidemiol 1996, 49:1401-5.

20. Guo $X$, Li J, Pang W, Zhao M, Luo Y, Sun Y, Hu D: Sensitivity and specificity of ankle-brachial index for detecting angiographic stenosis of peripheral arteries. Circ J 2008, 72:605-10.

21. Holland-Letz T, Endres HG, Biedermann S, Mahn M, Kunert J, Groh S, Pittrow D, von Bilderling P, Sternitzky R, Diehm C: Reproducibility and reliability of the ankle-brachial index as assessed by vascular experts, family physicians and nurses. Vasc Med 2007, 12:105-12.

22. Alzamora MT, Baena-Díez JM, Sorribes M, Forés $R$, Toran $P$, Vicheto $M$, Pera G, Reina MD, Albaladejo C, Llussà J, Bundó M, Sancho A, Heras A, Rubiés J, Arenillas JF, PERART study: Peripheral Arterial Disease study (PERART): prevalence and predictive values of asymptomatic peripheral arterial occlusive disease related to cardiovascular morbidity and mortality. BMC Public Health 2007, 7:348.
23. Executive summary of the third report of the Nacional Colesterol Education (NCEP): Expert Panel on Detection, Evaluation and Treatment of High Cholesterol in Adults(Adults Treatment Panel III). JAMA 2001, 285:2486-2497.

24. Burnham KP, Anderson DR: Model selection and multimodel inference: a practical information-theoretic approach. New-York: Springer-Verlag 2002, 496.

25. Tunstall-Pedoe H, Kuulasmaa K, Mahönen M, Tolonen H, Ruokokoski E, Philippe Amouyel, for the WHO MONICA Project: Contribution of trends in survival and coronary-event rates to changes in coronary heart disease mortality: 10-year results from 37 WHO MONICA Project populations. Lancet 1999, 353:1547-57.

26. Planas A, Clara A, Marrugat J, Pou JM, Gasol A, de Moner A: Age at onset of smoking is an independent risk factor in peripheral artery disease development. J Vasc Surg 2002, 35:506-9.

27. Manzano L, Mostaza JM, Suárez C, Cairols M, Redondo R, Valdivielso P, Monte R, Blázquez JC, Ferreira EM, Trouillhet I, González-Igual JJ, SánchezZamorano MA, en Representación del Estudio MERITO: Value of the anklebrachial index in cardiovascular risk stratification of patients without known atherothrombotic disease. MERITO study. Med Clin (Barc) 2007, 128:241-6.

28. Vicente I, Lahoz C, Taboada M, García A, San Martín MA, Terol I, Laguna F, García-lglesias F, Mostaza JM: Prevalence of an abnormal ankle-brachial index in relation to the cardiovascular risk estimated by the Framingham function. Med Clin (Barc) 2005, 124:641-4.

29. Lahoz C, Vicente I, Laguna F, García-lglesias MF, Taboada M, Mostaza JM: Metabolic syndrome and asymptomatic peripheral artery disease in subjects over 60 years of age. Diabetes Care 2006, 29:148-50.

30. Bundo M, Auba J, Valles R, Torner O, Perez AM, Massons J: Peripheral arterial disease in Diabetes mellitus. Aten Primaria 1998, 22:5-11.

31. Masia R, Pena A, Marrugat J, Sala J, Vila J, Pavesi M, Covas M, Aubo C, Elosua R: High prevalence of cardiovascular risk factors in Gerona, Spain, a province with low myocardial infarction incidence. REGICOR Investigators. J Epidemiol Community Health 1998, 52:707-715.

32. Tunstall-Pedoe $\mathrm{H}$, Kuulasmaa $\mathrm{K}$, Mahönen $\mathrm{M}$, Tolonen $\mathrm{H}$, Ruokokoski E, Philippe Amouyel, for the WHO MONICA Project: Contribution of trends in survival and coronary-event rates to changes in coronary heart disease mortality: 10-year results from 37 WHO MONICA Project populations. Lancet 1999, 353:1547-57.

33. Boix R, del Barrio JL, Saz P, Reñé R, Manubens JM, Lobo A, Gascón J, de Arce A, Díaz-Guzmán J, Bergareche A, Bermejo-Pareja F, de Pedro-Cuesta J, Spanish Epidemiological Study Group on Ageing: Stroke prevalence among the Spanish elderly: an analysis based on screening surveys. BMC Neurol 2006, 6:36.

34. Rothwell PM, Coull AJ, Giles MF, Howard SC, Silver LE, Bull LM, Gutnikov SA, Edwards P, Mant D, Sackley CM, Farmer A, Sandercock PA, Dennis MS, Warlow CP, Bamford JM, Anslow P, Oxford Vascular Study: Change in stroke incidence, mortality, case-fatality, severity, and risk factors in Oxfordshire, UK from 1981 to 2004 (Oxford Vascular Study). Lancet 2004, 363:1925-1933.

35. Meijer WT, Hoes AW, Rutgers D, Bots ML, Hofman A, Grobbee DE: Peripheral arterial disease in the elderly: The Rotterdam study. Arterioscler Thromb Vasc Biol 1998, 18:185-92.

36. Fowkes FG, Housley E, Cawood EH, Macintyre CC, Ruckley CV, Prescott RJ: Edinburgh Artery Study: Prevalence of asymptomatic and symptomatic peripheral arterial disease in the general population. Int J Epidemiol 1991, 20:384-92.

37. Coni M, Tennison B, Troup M: Prevalence of lower extremity arterial disease among elderly people in the community. Br J Gen Pract 1992, 42:149-152

38. Fowkes FG, Murray GD, Butcher I, Heald CL, Lee RJ, Chambless LE, Folsom AR, Hirsch AT, Dramaix M, deBacker G, Wautrecht JC, Kornitzer M, Newman AB, Cushman M, Sutton-Tyrrell K, Fowkes FG, Lee AJ, Price JF, d'Agostino RB, Murabito JM, Norman PE, Jamrozik K, Curb JD, Masaki KH, Rodríguez BL, Dekker JM, Bouter LM, Heine RJ, Nijpels G, Stehouwer CD, Ferrucci L, McDermott MM, Stoffers HE, Hooi JD, Knottnerus JA, Ogren M, Hedblad B, Witteman JC, Breteler MM, Hunink MG, Hofman A, Criqui MH, Langer RD, Fronek A, Hiatt WR, Hamman R, Resnick HE, Guralnik J, McDermott MM: Ankle brachial index combined with Framingham Risk 
Score to predict cardiovascular events and mortality: a meta-analysis. Ankle Brachial Index Collaboration. JAMA 2008, 300:197-208.

39. Kenchaiah S, Gaziano JM, Vasan RS: Impact of obesity on the risk of heart failure and survival after the onset of heart failure. Med Clin North Am 2004, 88:1273-94.

40. Nicoletti I, Cicoira M, Morando G, Benazzi C, Prati D, Morani G, Rossi A, Zardini P, Vassanelli C: Impact of body mass index on short-term outcome after acute myocardial infarction: does excess body weight have a paradoxical protective role?. Int J Cardiol 2006 107:395-9.

41. Taxes d'Incidència i prevalença a l'Atenció Primària: Mètodes per a la seva obtenció. Barcelona: Fundació Jordi Gol i Gurina 2002.

\section{Pre-publication history}

The pre-publication history for this paper can be accessed here:http://www. biomedcentral.com/1471-2458/10/38/prepub

doi:10.1186/1471-2458-10-38

Cite this article as: Alzamora et al:: The Peripheral Arterial disease study (PERART/ARTPER): prevalence and risk factors in the general population. BMC Public Health 2010 10:38.

\section{Submit your next manuscript to BioMed Central} and take full advantage of:

- Convenient online submission

- Thorough peer review

- No space constraints or color figure charges

- Immediate publication on acceptance

- Inclusion in PubMed, CAS, Scopus and Google Scholar

- Research which is freely available for redistribution

Submit your manuscript at www.biomedcentral.com/submit 